\title{
In Vivo Binding of the Cry11Bb Toxin of Bacillus thuringiensis subsp. medellin to the Midgut of Mosquito Larvae (Diptera: Culicidae)
}

\author{
Lina María Ruiz, César Segura/*, Judith Trujillo**, Sergio Orduz/***/+
}

\begin{abstract}
Unidad de Biotecnología y Control Biológico, Corporación para Investigaciones Biológicas, Medellín, Colombia *Facultad de Medicina, Universidad de Antioquia, Medellín, Colombia **Facultad de Medicina, Universidad Pontificia Bolivariana, Medellín, Colombia ***Universidad de Pamplona, Pamplona (NS), Colombia
\end{abstract}

Bacillus thuringiensis subsp. medellin produces numerous proteins among which 94 kDa known as CryllBb, has mosquitocidal activity. The mode of action of the Cry11 proteins has been described as similar to those of the Cryl toxins, nevertheless, the mechanism of action is still not clear. In this study we investigated the in vivo binding of the $\mathrm{Cry} 11 \mathrm{Bb}$ toxin to the midgut of the insect species Anopheles albimanus, Aedes aegypti, and Culex quinquefasciatus by immunohistochemical analysis. Spodoptera frugiperda was included as negative control.

The Cryl1Bb protein was detected on the apical microvilli of the midgut epithelial cells, mostly on the posterior midgut and gastric caeca of the three mosquito species. Additionally, the toxin was detected in the Malpighian tubules of An. albimanus, Ae. aegypti, Cx. quinquefasciatus, and in the basal membrane of the epithelial cells of Ae. aegypti midgut. No toxin accumulation was observed in the peritrophic membrane of any of the mosquito species studied. These results confirm that the primary site of action of the Cryll toxins is the apical membrane of the midgut epithelial cells of mosquito larvae.

Key words: Diptera - immunohistochemistry - in vivo binding - Bacillus thuringiensis - Cry11Bb toxin

Mosquitoes are vectors of important tropical diseases such as malaria, yellow fever, and dengue. Control of mosquito vectors has been accomplished with bioinsecticides developed with the bacteria Bacillus thuringiensis subsp. israelensis and B. sphaericus. B. thuringiensis subsp. israelensis produces Cry4Aa, Cry4Ba, Cry10Aa, Cry11Aa, and Cyt1Aa toxins, while B. sphaericus produces a binary toxin. Resistance of several populations of Culex mosquitoes to B. sphaericus toxin in different regions of the world has been reported (Rao et al. 1995, Regis et al. 1995). Resistance to B. thuringiensis subsp. israelensis has not been reported in the field, although resistant mosquitoes populations have thus been selected in the laboratory (Georghiou \& Wirth 1997, Wirth et al. 1998). For these reasons and due to the severe impact on public health of the diseases transmitted by mosquitoes, interest on identification of new strains, and active toxins against mosquitoes has increased resulting in the discovery of new toxins (Schnepf et al. 1998). The Cry11Bb toxin produced by $B$. thuringiensis subsp. medellin is active against different species of mosquito larvae (Orduz et al. 1994, 1998), and could represent a new alternative for mosquito larvae control.

Financial support: Comité para el Desarrollo de la Investigación, Universidad de Antioquia, Colciencias, and Corporación para Investigaciones Biológicas

${ }^{+}$Corresponding author. Fax: +574-441.5514. E-mail: sorduz@cib.org.co

Received 14 July 2003

Accepted 7 January 2004
The Cry $11 \mathrm{Bb}$ protein requires a proteolytic processing of the $94 \mathrm{kDa}$ protoxin in order to produce the 30 and $35 \mathrm{kDa}$ active fragments, through an intermediate $68 \mathrm{kDa}$ carried-out by intestinal proteases of the target insect (Segura et al. 2000). The mode of action of Cry proteins has been described based mainly on B. thuringiensis lepidopteran active toxins. The active fragments specifically interact with brush border membranes of the midgut's epithelial cells (Van Rie et al. 1990), with the irreversible binding being fundamental for toxicity (Rajamohan \& Charles 1995, Abdul-Rauf \& Ellar 1999, Aronson \& Shai 2001). Later on in the process, pores are formed, that possibly require the intermolecular interaction among several monomers of the toxin (Aronson et al. 1999, Soberon et al. 2000). These pores alter the permeability of the membrane (Luo et al. 1999), cause inhibition of amino acid transport (Parenti et al. 1995), with cellular death occurring due to an osmotic lysis mechanism.

The analyses of the in vivo and in vitro binding of the Cry4Aa, Cry4Ba, and Cry11Aa B. thuringiensis subsp. israelensis toxins in the midgut of the An. gambiae larvae have shown that these toxins are located in the apical microvilli of the posterior midgut with a mild binding being observed in the anterior midgut, suggesting that in the posterior midgut are receptors present with higher affinity or at higher concentration (Ravoahangimalala et al. 1993, Ravoahangimalala \& Charles 1995). The binding of the toxin to the apical microvilli of the midgut or to the midgut vesicles has generally been correlated with insect's susceptibility to the particular toxin, however, binding does not necessarily mean that the Cry protein is toxic (Ferré et al. 1991, Bravo et al. 1992a, Feldman et al. 1995).

Binding assays with the ${ }^{125}$ I-radiolabeled $68 \mathrm{kDa}$ intermediate incubated with Aedes aegypti brush border 
membrane vesicles (BBMV), showed a specific and saturable interaction of the intermediate ${ }^{125} \mathrm{I}-68 \mathrm{kDa}$ with the BBMV of Ae. aegypti. On the other hand, ligand blot assays results with the 30 and $35 \mathrm{kDa}$ fragments to BBMV of Cx. quinquefasciatus, Ae. aegypti, and An. albimanus indicate that there is no binding, whereas the $94 \mathrm{kDa}$ and $68 \mathrm{kDa}$ fragments showed binding to the mosquitoes BBMV (Segura 2001).

In this study, we investigated the in vivo binding of the Cry $11 \mathrm{Bb}$ toxin to the mosquito larvae midgut, through immunohistochemical methods in order to determine the primary site of action of this toxin.

\section{MATERIALS AND METHODS}

Insects - Larvae from the three mosquito species used (Ae. aegypti, An. albimanus, Cx. quinquefasciatus) and the lepidopteran Spodoptera frugiperda were maintained under laboratory conditions at $30 \pm 2^{\circ} \mathrm{C}$ under a $12: 12$ (light:dark) photoperiod in the insectary of the Corporación para Investigaciones Biológicas, Medellín, Colombia. Mosquitoes were fed with soybean powder. S. frugiperda was fed with an artificial diet based on bean (Arango et al. 2002), and included as a negative control in which binding of Cry $11 \mathrm{Bb}$ protein is not expected to occur.

Solubilization and purification of the Cry $11 B b \delta$-endotoxin - The Cry $11 \mathrm{Bb}$ protoxin was obtained from the acrystalliferous recombinant strain SPL-407 of $B$. thuringiensis subsp. thuriengiensis that had been transformed with the plasmid pSOB and contained a 3.1-kb insert of DNA encoding the Cry11Bb protoxin (Orduz et al. 1998). These cells were grown in $250 \mathrm{ml}$ of $\mathrm{M}$-one medium (Restrepo et al. 1997) supplemented with erythromycin $(25 \mu \mathrm{g} / \mathrm{ml})$ for $48 \mathrm{~h}$ at $30^{\circ} \mathrm{C}$; and then transferred to a 201 fermentor containing 101 of culture medium; the fermentation conditions have already been published (Vallejo et al. 1999). The final whole culture was harvested by centrifugation, the pellet was treated with $1 \mathrm{M} \mathrm{NaCl}$ for $1 \mathrm{~h}$ with shaking at $300 \mathrm{rpm}$, at $30^{\circ} \mathrm{C}$; the salt was removed by washing twice in water supplemented with $10 \mathrm{mM}$ of phenylmethylsulfonylflouride (PMSF) (Sigma) and $10 \mathrm{mM}$ ethylenediaminetetraacetic acid (EDTA) at $4^{\circ} \mathrm{C}$. The resulting pellet was treated with $1 \mathrm{M} \mathrm{NaCl} / 1 \%$ Triton-X100 at $4{ }^{\circ} \mathrm{C}$, salt and detergent were removed with extensive washes by centrifugation at $9000 \mathrm{~g}$ for $15 \mathrm{~min}$ in distilled water supplemented with $1 \mathrm{mM}$ PMSF and $100 \mathrm{mM}$ EDTA at $4{ }^{\circ} \mathrm{C}$, and the pellet was resuspended in $50 \mathrm{ml}$ of $50 \mathrm{mM}$ cyclohexylaminopropane sulfonic acid (CAPS) $\mathrm{pH}$ 10.6/ $0.05 \% \beta$-mercaptoethanol, and left in the shaker for $1 \mathrm{~h}$ at $37^{\circ} \mathrm{C}$, at $300 \mathrm{rpm}$. The supernatant containing the soluble toxin was centrifuged at $15,000 \mathrm{~g}$ for $1 \mathrm{~h}$ at $4^{\circ} \mathrm{C}$, and protein concentration was determined by the Bradford method with bovine serum albumin-BSA as standard (Bradford 1976).

Purification of the Cry $11 \mathrm{Bb}$ toxin was performed through ionic exchange chromatography in a fast performance liquid chromatograph (FPLC - Bio-Rad, BioLogic LP) using an anionic exchange column Econopack High Q (Bio-Rad), previously balanced with $50 \mathrm{mM}$ CAPS, $\mathrm{pH}$ 10.6. The soluble protein $(50 \mathrm{mg})$ was filtered through a $0.22 \mu \mathrm{m}$ filter and applied to a $5 \mathrm{ml}$ bed of a Q-sepharose column. The toxin was eluted from the column with a $\mathrm{NaCl}$ gradient from 0 to $1 \mathrm{M}$ in $50 \mathrm{mMCAPS}$ (pH 10.6) during 40 min. The collected fractions were analyzed through sodium dodecyl sulfate $10 \%$ polyacrilamide gel electrophoresis (SDS-PAGE), and fractions were finally aliquoted and stored at $-20^{\circ} \mathrm{C}$ until used.

Cry $11 \mathrm{Bb}$ treatments - Early fourth instars of the mosquito species under starvation for $20 \mathrm{~h}$ were treated with $21.5 \mu \mathrm{g} / \mathrm{ml}$, which corresponded to approximately 500 -fold the half lethal concentration for the mosquitoes for variable periods of time, $0.25,0.5,0.75,1$, and $2 \mathrm{~h}$, this concentration had been previously used by Orduz et al. (1994). When intoxication and mortality were observed, larvae were removed to a petri dish with distilled water to wash the toxin excess. Fifth instar S. frugiperda larvae were fed with a micro-syringe with $10 \mu \mathrm{l}$ of Cry $11 \mathrm{Bb}$ toxin solution containing $10 \mu \mathrm{g} / \mathrm{ml}$ while control larvae were treated with $10 \mu \mathrm{l}$ of $1 \%$ BSA.

Preparation and sectioning of insect tissues - After exposure to the Cry $11 \mathrm{Bb}$ treatments, mosquito larvae were placed in neutral formaldehyde. After feeding $S$. frugiperda larvae with the toxin, guts were dissected at $4{ }^{\circ} \mathrm{C}$ and the midgut was fixed in neutral formaldehyde. Mosquito larvae and their midguts were dehydrated in increasing isopropyl alcohol concentrations, rinsed in xylol and included in paraffin. Five $\mu \mathrm{m}$ sections were obtained and placed in carriers loaded with 2\% 3-aminopropyltriethoxy-silane (Bravo et al. 1992b).

Antibodies - Mice polyclonal antibody against Cry $11 \mathrm{Bb}(94 \mathrm{kDa})$ was prepared as indicated by Harlow and Lane (1999). Sensibilization and specificity were evaluated by ELISA and Western blot with 1:100, 1:1000 dilutions, respectively, of the mice sera using standard techniques (Voller et al. 1980). The immunodetection was performed in combination with a peroxidase-conjugated goat IgG fraction to mouse IgG (whole molecule) (ICN Pharmaceuticals, Eappel).

Immunohistochemical localization of the Cry11Bb toxin - Detection of Cry $11 \mathrm{Bb}$ toxin was performed through modifications of the technique developed by Bravo et al. (1992b). The sections were de-paraffinated in 100\% xylol and hydrated in decreasing concentrations of ethanol, washed in distilled water and balanced in Tris buffer saline (TBS) $(66 \mathrm{mM} \mathrm{NaCl}, 1.6 \mathrm{mM} \mathrm{KCl}, 25 \mathrm{mM}$ Tris base, $\mathrm{pH}$ 7.4). Antigen unmasking was carried-out with $1 \mathrm{mg} / \mathrm{ml}$ of trypsin in $0.2 \mathrm{~N} \mathrm{HCl}$ for $5 \mathrm{~min}$ at room temperature. Trypsin was inactivated by addition of $0.5 \mathrm{mM}$ PMSF with incubation for $5 \mathrm{~min}$ and then the endogen peroxidase activity was blocked by incubating the tissue sections with $0.5 \%$ $\mathrm{H}_{2} \mathrm{O}_{2}$ for 30 min and $6 \% \mathrm{H}_{2} \mathrm{O}_{2}$ for 15 min in methanol, at room temperature. The tissue section boundaries were marked with hydrophobic pencil (DAKO) in order to achieve uniformity in the incubations. The tissue samples were blocked with 3\% BSA in TBS for $1 \mathrm{~h}$ at a room temperature, rinsed with TTBS ( $0.5 \%$ Triton-X100 TBS ), and incubated $1 \mathrm{~h}$ at $37^{\circ} \mathrm{C}$ in a humid chamber with $1: 1000$ of the polyclonal antibody raised in mouse against the Cry $11 \mathrm{Bb}$ protein diluted in TBS with $1 \% \mathrm{BSA}$, incubated for $40 \mathrm{~min}$ a $37^{\circ} \mathrm{C}$ in humid chamber with 1:200 of peroxidase-conjugated goat $\mathrm{IgG}$ fraction to mouse $\mathrm{IgG}$, and washed again with TBS. Color development was achieved with 3,3-diaminobenzidine (DAB) in chromogen solution 
in imidazole- $\mathrm{HCl}$ buffer $\mathrm{pH} 7.5$ containing hydrogen peroxide and an antimicrobial agent (Liquid DAB large volume substrate-chromogen system DAKO) for $3 \mathrm{~min}$ at room temperature. The counterstaining of the tissue sections was performed with Harris hematoxilin for $10 \mathrm{~s}$ and ammoniacal water for $10 \mathrm{~s}$; the tissues were dehydrated in increasing concentrations of ethanol and clarified in xylol; finally, the sections were covered with entellan (Merk) mounting resin and analyzed by light microscopy.

\section{RESULTS}

Polyclonal antibodies against Cry $11 \mathrm{Bb}$ were able to detect the $94 \mathrm{kDa}$ protoxin, the $68 \mathrm{kDa}$ intermediate and the $35 \mathrm{kDa}$ form of the Cry11Bb toxin-Production of polyclonal antibodies anti-Cry11Bb1 was assessed by ELISA, obtaining a titre of $3.56\left(\log _{10}\right)$. These polyclonal antibodies obtained in mice recognized the $94 \mathrm{kDa}$ protoxin, as well as the products of the proteolytic processing, including the $68 \mathrm{kDa}$ intermediate and the $35 \mathrm{kDa}$ active fragment; however, the $30 \mathrm{kDa}$ active fragment was only weakly recognized by Western blot (Fig. 1).

Toxicological effects of the CryllBb toxin - In the treatments containing $21.5 \mu \mathrm{g} / \mathrm{ml}$ of Cry $11 \mathrm{Bb}$, approximately 500-fold the $\mathrm{LC}_{50}$ of the Cry $11 \mathrm{Bb}$ for Ae. aegypti, An. albimanus, and $C x$. quinquefasciatus, mosquito larvae intoxication was observed $30 \mathrm{~min}$ after exposure to the toxin and mortality increased 30 min later on for Ae. aegypti and $C x$. quinquefasciatus. The external toxicological symptoms were seen only $2 \mathrm{~h}$ after treatment in An. albimanus larvae. Toxic effects on $S$. frugiperda larvae were not observed after treatment with the Cry $11 \mathrm{Bb}$ toxin.

Immunohistochemical localization of the Cry $11 \mathrm{Bb}$ toxin on the apical microvilli of the midgut ephitelial cells - Binding of the Cry $11 \mathrm{Bb}$ toxin to mosquito larvae tissues was observed after 15 min exposure to the Cry $11 \mathrm{Bb}$ toxin by a brownish staining at the apical microvilli, with

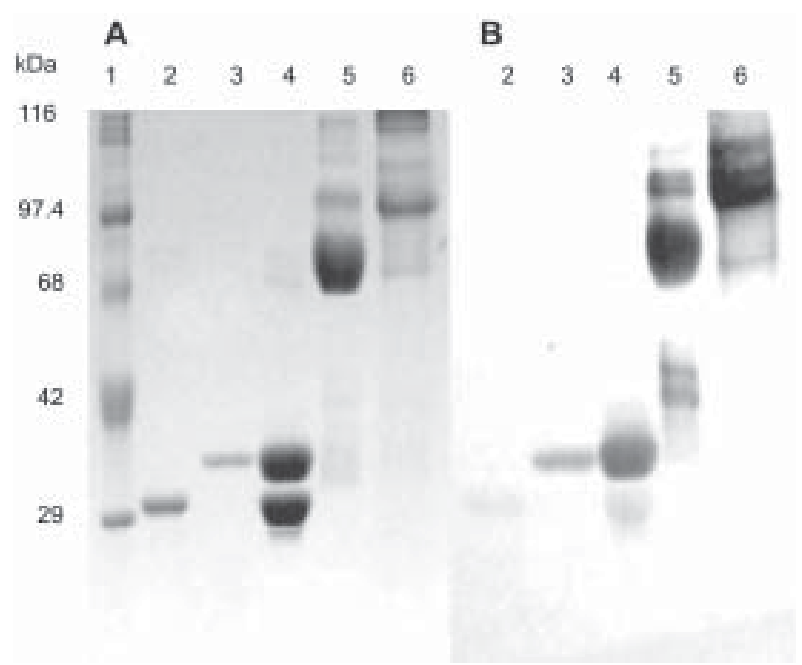

Fig. 1A: sodium dodecyl sulfate-polyacrilamide gel electrophoresis; B: immunoblot of different forms of the Cry11Bb toxin of Bacillus thuringiensis subsp. medellin. Molecular weight markers are indicated in kilodaltons (kDa). Lanes - 1: MWM; 2: $30 \mathrm{kDa}$ protein; 3: $35 \mathrm{kDa}$ protein; 4: 30/35 kDa protein; 5: $68 \mathrm{kDa}$ protein; 6: 94 $\mathrm{kDa}$ protein the staining intensity remaining unchanged from this time onwards. Control larvae not exposed to the Cry $11 \mathrm{Bb}$ toxin or those in which the polyclonal antibody against Cry11Bb was omitted, did not show the brownish coloration (Figs $2 \mathrm{~A}, \mathrm{D}, \mathrm{G})$ in none of the mosquito species tested. The Cry $11 \mathrm{Bb}$ toxin was also detected on the apical microvilli and in the basal membrane of the posterior midgut epithelium cells of Ae. aegypti, An. albimanus, and Cx. quinquefasciatus after 15 min exposure to the toxin (Figs 2B, $\mathrm{E}, \mathrm{H}$, respectively). In the gastric caeca of the three mosquito species, strong signals were also observed (Figs 2C, F, I), while in anterior midgut the signal was weak (data not shown).

Histopathological effects of the CryllBb toxin in mosquito larvae - The general histopathological changes induced by the Cry $11 \mathrm{Bb}$ toxin in the mosquito larvae gut epithelia included vacuolization of the cytoplasm, hypertrophy of the epithelial cells and their nucleus, brush border membrane impairment, and disintegration of the cells. After $2 \mathrm{~h}$ exposure to the Cry $11 \mathrm{Bb}$ toxin, vacuolization of the cytoplasm and swollen nuclei were observed (Fig. 3A), midgut columnar cells of the mosquito larvae were elongated (Fig. 3B), the cells were disrupted at the apical region with vesicle formation, lysis and leakage of cytoplasm material into the gut lumen (Figs 3B, C). Additionally, in Ae. aegypti and An. albimanus larvae, the Cry $11 \mathrm{Bb}$ toxin was detected in the Malpighian tubules 15 and 45 min after treatment with the toxin, respectively, while in Cx. quinquefasciatus larvae, the Cry $11 \mathrm{Bb}$ toxin was only detected in the Malpighian tubule microvilli junctions $1 \mathrm{~h}$ after treatment, and $1 \mathrm{~h}$ later these structures had shrunken (Fig. 3D).

Cry $11 \mathrm{Bb}$ protein was detected in a diffuse way inside the cells and in the apical and basal parts of S. frugiperda gut epithelium (Fig. 4B), in spite of the faint binding, the midgut of $S$. frugiperda cells had no histopathological changes (Fig. 4B).

\section{DISCUSSION}

Present in vivo experiments showed that the Cry $11 \mathrm{Bb}$ toxin bound preferentially to the posterior midgut apical microvilli and the gastric caeca of the evaluated mosquito species; and therefore, the epithelial cells of the midgut could be considered as the main target of this toxin. The Cry $11 \mathrm{Bb}$ toxin preferred localization in gastric caeca and the posterior midgut of mosquito larvae may be due to a higher concentration of receptor molecules or of molecules with higher binding affinity. Differential binding in the anterior and posterior midgut of dipterans has already been observed in mosquito larvae treated with $B$. thuringiensis or B. sphaericus toxins (Ravoahangimalala et al. 1993, Ravoahangimalala \& Charles 1995). Toxicological effects of the Cry $11 \mathrm{Bb}$ toxin in mosquito larvae were in agreement with the data reported by Orduz et al. (1994).

The immunolocalization of the Cry $11 \mathrm{Bb}$ toxin observed in the basal membrane of Ae. aegypti and An. albimanus larvae was possibly due to the toxin's leakage or at least part of it from the midgut lumen to the basal area of the epithelium after disruption of the cellular integrity of the midgut tissue. The deterioration of the intercellular junc- 
tions could be a consequence of the damage caused by the Cry $11 \mathrm{Bb}$ toxin at the cellular membrane level, as this situation has also been observed in Heliothis virescens midgut after $3 \mathrm{~h}$ exposure to the Cry1 Ac (Forcada et al. 1999).

Additionally, the Cry $11 \mathrm{Bb}$ toxin was observed in $C x$. quinquefasciatus larval midgut $15 \mathrm{~min}$ after treatment, and $1 \mathrm{~h}$ after exposure to the toxin on the apical microvilli of the Malpighian tubules. It is unknown if the binding of the Cry $11 \mathrm{Bb}$ toxin to the Malpighian tubules contributes to mortality of mosquito larvae. The binding sites of several Cry toxins have been located on the Malpighian tubule epithelium of some insect species; however, their role in toxicity has not been fully characterized. Although Maddrell et al. (1989) reported important changes in the trans-epithelial potential difference of Rhodnius prolixus Malpighian tubules after treatment with $B$. thuringiensis toxin and Reisner et al. (1989) located B. thuringiensis kurstaki $\delta$-endotoxins on the Malpighian tubules of Calpodes ethlius larvae and described its effect as inhibitory of fluid secretion causing cytological alterations, which ended-up in cellular lysis and epithelial damage, Denolf et al. (1993) reported binding of Cry1 Ab1, Cry1Ac1, and Cry1Bal toxins to the Malpighian tubules of Ostrinia nubilalis, but did not suggest a relevant role in the mortality of this lepidopteran. It is possible that the damage caused by the Cry $11 \mathrm{Bb}$ toxin in the mosquito larvae midgut intercellular junctions, as seen in Fig. 3B, could have permitted toxin leakage into the hemolymph to reach the Malpighian tubules, producing shrinking of their epithelium (Fig. 3D), and perhaps impairing their osmoregulatory functions before larval death.

Although S. frugiperda was not susceptible to the toxin, the weak localization of the Cry $11 \mathrm{Bb}$ protein in its midgut, could be the result of non-specific binging or to low affinity binding to a putative receptor with some degree of homology to the mosquito larvae receptors. However, this binding does not guarantee toxicity (Ferré et al. 1991, Bravo et al. 1992a, Feldman et al. 1995).

Some studies have suggested that Cry1 toxins could have more than one binding site in Heliothis sp., Spodoptera sp., and Manduca sexta (Oddu et al. 1993, Masson et al. 1995). It is assumed that the mode of action of the Cry 11 toxins is similar to that of Cry 1 toxins; therefore, it is possible that the Cry $11 \mathrm{Bb}$ toxin could have more than one receptor in the midgut apical microvilli of the mosquitoes evaluated as it has been suggested by Segura (2001).

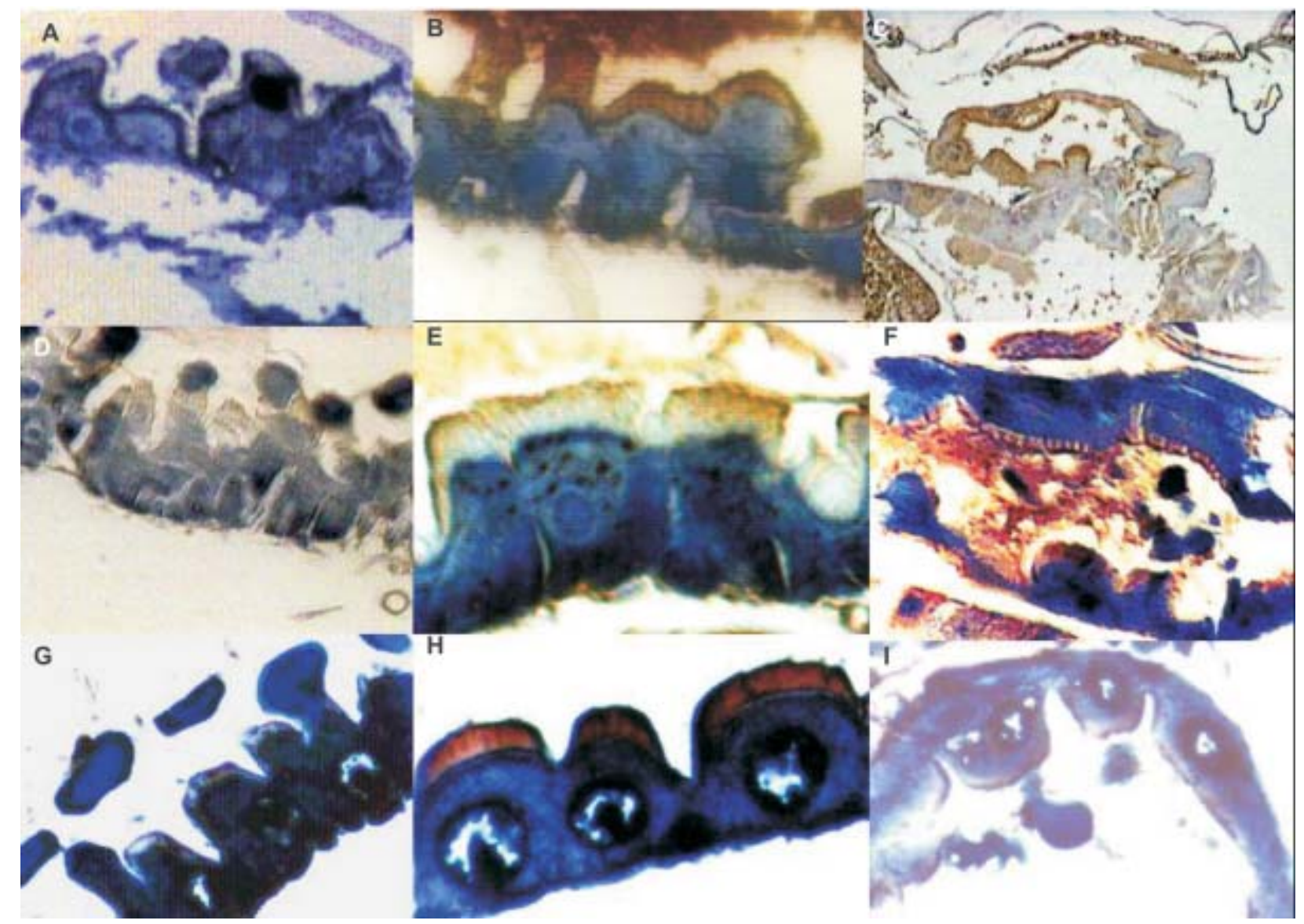

Fig. 2: immunohistochemical localization of the Cry11Bb toxin of Bacillus thuringiensis subsp. medellin on the apical microvilli of the midgut epithelial cells of mosquito larvae. Aedes aegypti (A, B, C), Anopheles albimanus (D, E, F), and Culex quinquefasciatus (G, H, I) pictures taken $1 \mathrm{~h}$ after exposure to the toxin. Control slides of the posterior midgut omitting the primary antibody (A, D, G). Positive signal in the posterior $(\mathrm{B}, \mathrm{E}, \mathrm{H})$ and gastric caeca $(\mathrm{C}, \mathrm{F}, \mathrm{I})$ of the mosquito species. Magnification $40 \mathrm{X}$ 
Previous in vitro binding studies have shown that the Cry $11 \mathrm{Bb}$ protoxin $(94 \mathrm{kDa})$ and the $68 \mathrm{kDa}$ intermediate form interact with Ae. aegypti brush border membrane vesicles, while the 30/35 kDa toxin does not (Segura 2001). The in vivo binding of Cry $11 \mathrm{Bb}$ to the apical microvilli of mosquito larvae, probably corresponds to the $68 \mathrm{kDa}$ form, since the $94 \mathrm{kDa}$ protoxin disappears in the midgut lumen
10 min after treating the larvae (Segura et al. 2000), and the binding pattern seen as the brownish staining was similar in all the analyzed times of the present study.

The information obtained by immunohistochemical techniques indicates that the midgut is the primary site for the action of the Cry11Bb toxin, being preferentially localized in gastric caeca and the posterior midgut. More-

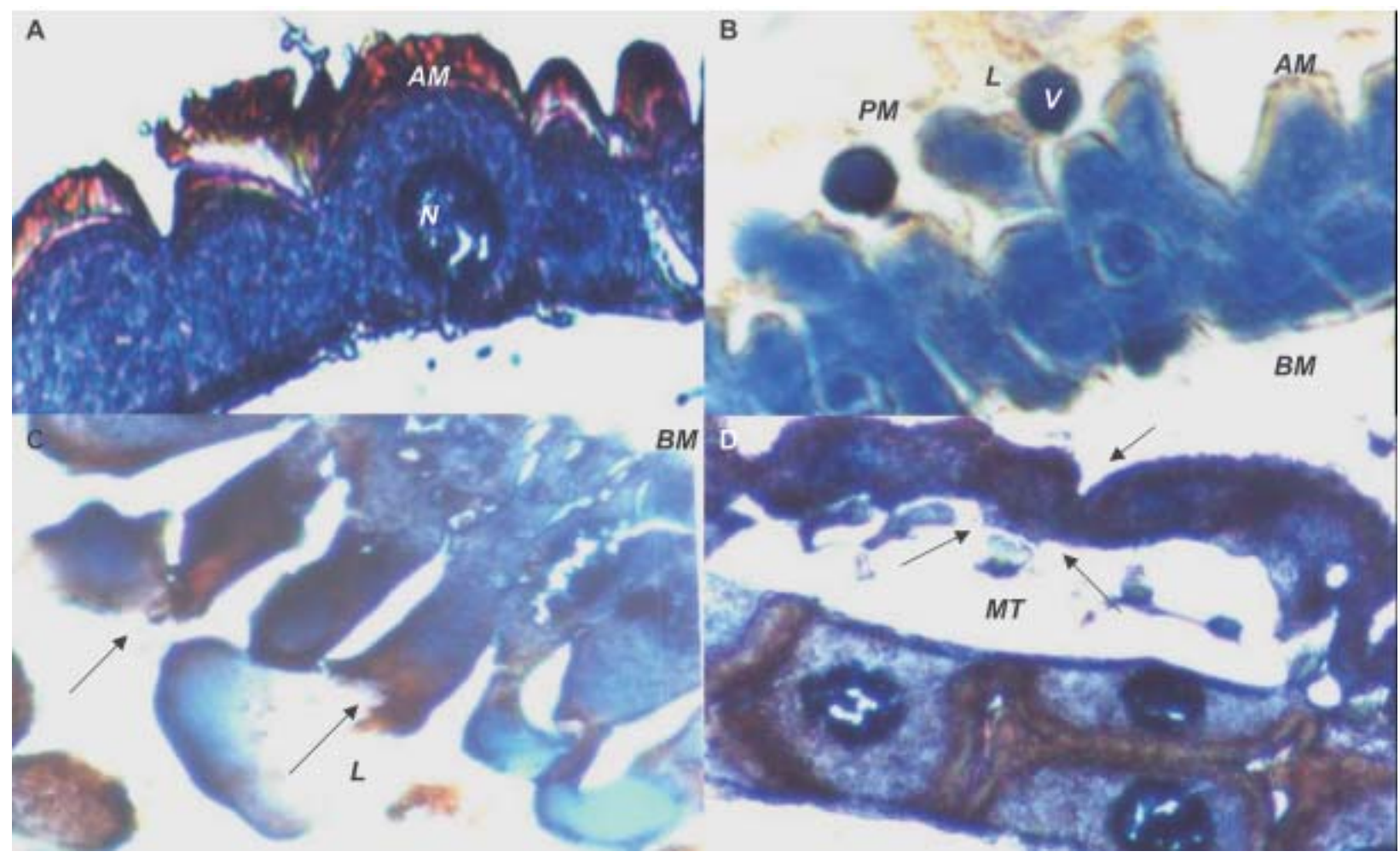

Fig. 3: hispathological effects of the Cry11Bb toxin Bacillus thuringiensis subsp. medellin in mosquito larvae after $2 \mathrm{~h}$ of exposure to the Cry $11 \mathrm{Bb}$ toxin. A: vacuolization of the cytoplasm and hypertrophy of the Culex quinquefasciatus epithelial cells and their nuclei; B: vesicle formation in the apical region of cell towards the midgut lumen of the Anopheles albimanus; C: arrows indicates lysis of columnar cells of $C x$. quinquefasciatus; $\mathrm{D}$ : localization of the protein Cry11Bb on the apical microvilli of the Malpighian tubules of $C x$. quinquefasciatus larvae $2 \mathrm{~h}$ after exposure to the toxin. The arrow indicates the shrunken tubules. AM: apical microvilli; BM: basal membrane; $L$ : midgut lumen; $P M$ : peritrophic membrane; $V$ : vesicles; $N$ : nucleus. Magnification $40 \mathrm{X}$

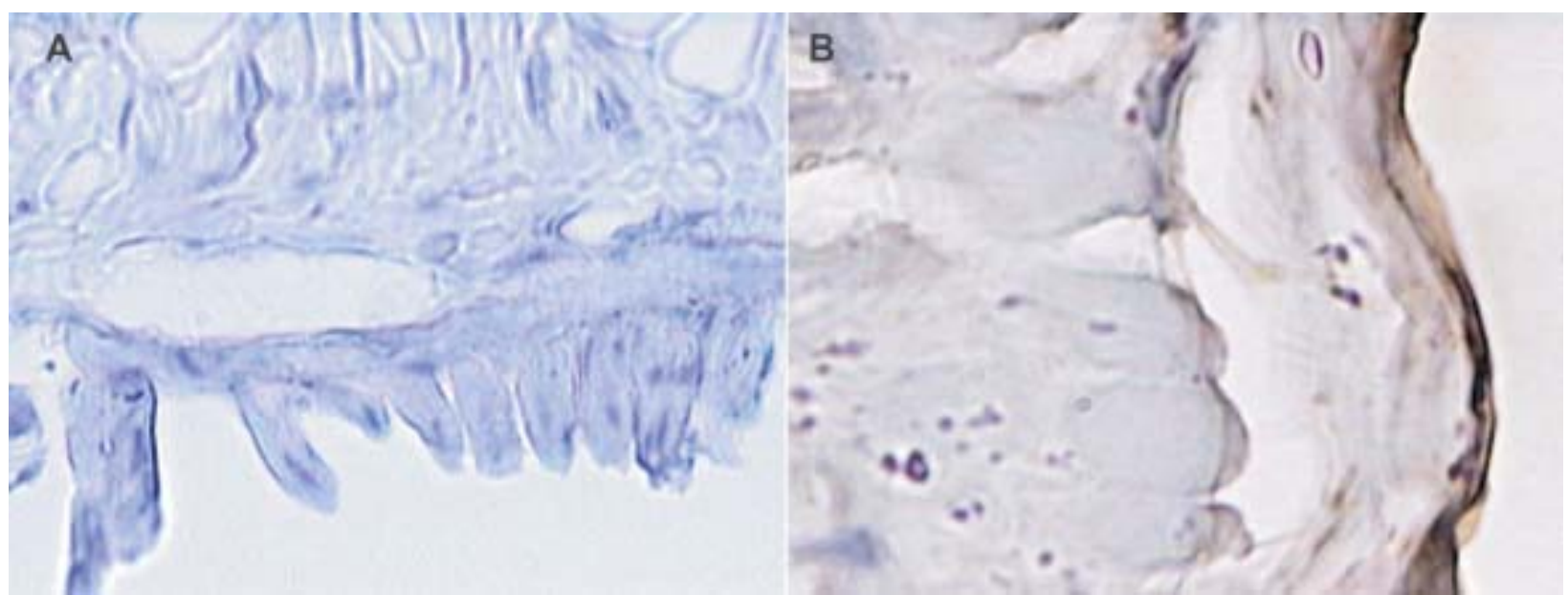

Fig. 4. immunohistochemical localization of Bacillus thuringiensis subsp. medellin protein Cry11Bb on the apical microvilli of epithelial cells of the midgut of Spodoptera frugiperda larvae. Omitting primary antibody control (A). Midgut with faint signals on the apical microvilli of the midgut and basal part of the epithelial cells (B). Magnification 100X 
over, the Cry $11 \mathrm{Bb}$ toxin was localized in the Malphigian tubules of Ae. aegypti An. albimanus, and Cx. quinquefasciatus larvae, which may indicate a possible relationship with the mode of action of this toxin. Further research that includes in vivo or in vitro homologous and heterologous competition assays will permit to know if the Cry $11 \mathrm{Aa}$ and Cry11Bb toxins share a common receptor. This type of research will contribute to the design of more effective biological control agents.

\section{REFERENCES}

Abdul-Rauf M, Ellar D 1999. Toxicity and receptor binding properties of a Bacillus thuringiensis CryIC toxin active against both Lepidoptera and Diptera. J Invertebr Pathol 73: 52-58.

Arango JA, Romero M, Orduz S 2002. Diversity of Bacillus thuringiensis strains from Colombia with insecticidal activity against Spodoptera frugiperda (Lepidoptera:Noctuidae). J Appl Microbiol 92: 466-474.

Aronson A, Shai Y 2001. Why Bacillus thuringiensis insecticidal toxins are so effective: unique features of their mode of action. FEMS Microbiol Lett 195: 1-8.

Aronson A, Geng C, Wu L 1999. Aggregation of Bacillus thuringiensis Cry1A toxins upon binding to target insect larval midgut vesicles. Appl Microbiol Biotechnol 65: 25032507.

Bradford MM 1976. A rapid and sensitive method for the quantitation of microgram quantities of protein utilizing the principle of protein-dye binding. An Biochem 72: 248254.

Bravo A, Hendricks K, Jansens S, Peferoen M 1992a. Immunocytochemical analysis of specific binding of Bacillus thuringiensis insecticidal crystal proteins to lepidopteran and coleopteran midgut membranes. J Invertebr Pathol 60: 247-253.

Bravo A, Jansens S, Peferoen M 1992b. Immunocytochemical localization of Bacillus thuringiensis insecticidal crystal proteins in intoxicated insects. J Invertebr Pathol 60: 237246.

Denolf P, Jansens S, Peferoen M, Degheele D, Van Rie J 1993. Two different Bacillus thuringiensis delta-endotoxin receptors in the midgut brush border membrane of the european corn borer, Ostrinia nubilalis (Hübner) (Lepidoptera: Pyralidae). Appl Microbiol Biotechnol 59: 1828-1837.

Feldmann F, Dullemans A, Waalwijh C 1995. Binding of the CryIVD toxin of Bacillus thuringiensis subsp. israelensis to larval dipteran midgut proteins. Appl Microbiol Biotechnol 61: 2601-2605.

Ferré J, Real MD, Van Rie J, Jansens S, Peferoen M 1991. Resistance to the Bacillus thuringiensis bioinsecticide in a field population of Plutella xylostella is due to a change in a midgut membrane receptor. Proc Natl Acad Sci USA 88: 5119-5123.

Forcada C, Alcácer E, Garcerá MD, Tato A, Martínez R 1999. Resistance to Bacillus thuringiensis Cry1 Ac toxin in three strains of Heliothis virescens: Proteolytic and SEM study of the larval midgut. Arch Insect Biochem Physiol 42: 5163.

Georghiou G, Wirth MC 1997. Influence of exposure to single versus multiple toxins of Bacillus thuringiensis subsp. israelensis on development of resistance in the mosquito Culex quinquefasciatus (Diptera: Culicidae). Appl Environ Microbiol 63: 1095-1101.

Harlow E, Lane D 1999. Using Antibodies: A Laboratory Manual, Cold Spring Harbor Laboratory Press, New York, $495 \mathrm{pp}$.
Luo K, Banks D, Adang M 1999. Toxicity, binding, and permeability analyses of four Bacillus thuringiensis Cry $1 \delta$-endotoxins using brush border membrane vesicles of Spodoptera exigua and Spodoptera frugiperda. Appl Microbiol Biotechnol 60: 457-464.

Maddrell SH, Overton JA, Ellar DJ, Knowles BH 1989. Action of activated $27.000 \mathrm{Mr}$ toxin from Bacillus thuringiensis var. israelensis on Malpighian tubules of the insect, Rhodnius prolixus. J Cell Sci 94: 601-608.

Masson L, Lu Y-J, Mazza A, Brousseau R, Adang M 1995. The Cry1A(c) receptor purified form Manduca sexta displays multiple specificities. J Biol Chem 270: 20309-20315.

Oddou P, Hartmann H, Radecke F, Geiser M 1993. Immunologically unrelated Heliothis sp. and Spodoptera sp. midgut membrane-proteins bind Bacillus thuringiensis CryIA(b)

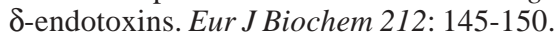

Orduz S, Diaz T, Thiéry I, Charles J-F, Rojas W 1994. Crystal proteins from Bacillus thuringiensis serovar. medellin. Appl Microbiol Biotechnol 40: 794-799.

Orduz S, Realpe M, Arango R, Murillo L, Delécluse A 1998. Sequence of the cry $11 \mathrm{Bb} 1$ gene from Bacillus thuringiensis subsp. medellin and toxicity analysis of its encoded protein. Biochim Biophys Acta 1388: 267-272.

Parenti P, Villa M, Hanozet G, Tasca M, Giordana B 1995. Interaction of the insecticidal crystal protein CryIA from Bacillus thuringiensis with amino acid transport into brush border membranes from Bombyx mori larval midgut. $J$ Invertebr Pathol 65: 35-42.

Rajamohan F, Alcantara E, Lee MK, Chen XJ, Curtis A, Dean D 1995. Single amino acid changes in domain II of Bacillus thuringiensis CryIAb $\delta$-endotoxin affect irreversible binding to Manduca sexta midgut membrane vesicles. J Bacteriol 177: 2276-2282.

Rao DR, Mani TR, Rajendran R, Joseph AS, Gajanana A, Reuben R 1995. Development of high level of resistance to Bacillus sphaericus in a field population of Culex quinquefasciatus from Kochi, India. J Amer Mosq Control Assoc 11: 1-5.

Ravoahangimalala O, Charles J-F 1995. In vitro binding of $\mathrm{Ba}$ cillus thuringiensis var. israelensis individual toxins to midgut cells of Anopheles gambiae larvae (Diptera: Culicidae). FEBS Lett 362: 111-115.

Ravoahangimalala O, Charles J-F, Shoeller-Raccaud J 1993. Immunological localization of Bacillus thuringiensis serovar israelensis toxins in midgut cells of intoxicated Anopheles gambiae larvae (Diptera: Culicidae). Res Microbiol 144: 271-278.

Regis L, Silva-Filha MHNL, de Oliveria CMF, Rios EM, da Silva SB, Furtado A 1995. Integrated control measures against Culex quinquefasciatus, the vector of filariasis in Recife. Mem Inst Oswaldo Cruz 90: 115-120.

Reisner W, Feir D, Lavrik P, Ryerse J 1989. Effect of Bacillus thuringiensis kurstaki d-endotoxin on insect Malpighian tubule structure and function. J Invertebr Pathol 54: 175190.

Restrepo N, Gutiérrez D, Patiño MM, Thiéry I, Delécluse A, Orduz S 1997. Cloning, expression and toxicity of a mosquitocidal toxin gene of Bacillus thuringiensis subsp. medellin. Mem Inst Oswaldo Cruz, 92: 257-262.

Schnepf E, Crickmore N, Van Rie J, Lereclus D, Baum J, Feitelson J, Zeigler DR, Dean DH 1998. Bacillus thuringiensis and its pesticidal crystal proteins. Microbiol Mol Biol Rev 62: 775-806.

Segura C 2001. Study on the Mode of Action of Bacillus thuringiensis subsp. medellin toxins, $\mathrm{PhD}$ Thesis, University of Antioquia, Medellin, Colombia.

Segura C, Guzman F, Patarroyo M, Orduz S 2000. Activation pattern and toxicity of the Cry11Bb1 toxin of Bacillus 
thuringiensis subsp. medellin. J Invertebr Pathol 76: 5662.

Soberón M, Pérez R, Núñez-Valdéz M, Lorence A, Gómez I, Sánchez J, Bravo A 2000. Evidence for intermolecular interaction as a necessary step for pore-formation activity and toxicity of Bacillus thuringiensis Cry1 Ab toxin. FEMS Microbiol Lett 191: 221-225.

Vallejo F, Gonzalez A, Posada A, Restrepo A, Orduz S 1999. Production of Bacillus thuringiensis subsp medellin by batch and fed-batch culture. Biotechnol Tech 13: 279-281.

Van Rie J, Jansens S, Höfte H, Degheele D, Van Mellaert H 1990. Receptors on the brush border membrane of the in- sect midgut as determinants of the specificity of Bacillus thuringiensis delta-endotoxins. Appl Microbiol Biotechnol 56: $1378-1385$.

Voller A, Bidwell D, Burek C 1980. An enzyme-linked immunosorbent assay (ELISA) for antibodies to thyroglobulin. Proc Soc Exp Biol Med 163: 402-405.

Wirth MC, Delecluse A, Federici BA, Walton WE 1998. Variable cross-resistance to Cry11B from Bacillus thuringiensis subsp. jegathesan in Culex quinquefasciatus (Diptera: $\mathrm{Cu}-$ licidae) resistant to single or multiple toxins of Bacillus thuringiensis subsp. israelensis. Appl Environ Microbiol 64: 4174-4179. 